\section{Effect of Style of Cut and Storage on Phenolic Composition and Antioxidant Activity of Fresh-cut Sweetpotatoes}

\author{
Malkeet S. Padda ${ }^{1}$ and David H. Picha \\ School of Plant, Environmental and Soil Sciences, Louisiana State University \\ Agricultural Center, J.C. Miller Hall, Baton Rouge, LA 70803
}

Additional index words. Ipomoea batatas, total phenolics, chlorogenic acid, caffeic acid, dicaffeoylquinic acid

\begin{abstract}
Three different style fresh-cut (shredded, French fry, and sliced) sweetpotatoes [Ipomoea batatas (L.) Lam.] were stored at 0 and $5{ }^{\circ} \mathrm{C}$ for 4 and 8 days. At specified storage intervals, the fresh-cut sweetpotatoes were analyzed for total phenolics, individual phenolic acids, and antioxidant activity. Sweetpotato tissue analyzed immediately after cutting was considered the control. Storage at $5{ }^{\circ} \mathrm{C}$ resulted in an increase in total phenolics in all types of fresh-cut sweetpotatoes, except in shredded tissue analyzed after 4 days of storage. However, at $0{ }^{\circ} \mathrm{C}$, only sliced tissue accumulated higher total phenolics than the control. In general, antioxidant activity in all fresh-cut sweetpotatoes held at $5^{\circ} \mathrm{C}$ was higher than in the control. No significant increase in antioxidant activity was observed in shredded sweetpotatoes stored at $0{ }^{\circ} \mathrm{C}$. Chlorogenic acid followed by 3,5-dicaffeoylquinic acid were the predominant phenolic acids present in fresh-cut sweetpotatoes. The highest content of chlorogenic acid $\left(539.9 \mu \mathrm{g} \cdot \mathrm{g}^{-1} \mathrm{dry}\right.$ weight $)$ in sliced tissue stored for 8 days at $5{ }^{\circ} \mathrm{C}$ was $\approx 6$-fold higher than in the control $\left(88.3 \mu \mathrm{g} \cdot \mathrm{g}^{-1} \mathrm{dry}\right.$ weight). No significant development of tissue browning, off-odors, or off-flavors were observed after 8 days of storage and the products were considered to be marketable.
\end{abstract}

Fresh-cut fruits and vegetables are popular value-added convenience foods widely available worldwide. Consumption of freshcut produce has grown at a rapid pace during the last 10 years and new product development is still occurring (United Fresh Produce Association, pers. comm., 2007). Fresh-cut products are substituting for frozen items in certain cases. A wide variety of fresh-cut products are now commercially available for direct consumer use or for further processing by restaurants and fast-food chains. Many consumers of fruit and vegetables base their purchasing decisions on product convenience and quality.

Fruits and vegetables are rich sources of phenolic compounds, which can act as antioxidant or free radical scavengers in the human body to reduce the risks of certain types of cancer, diabetes, and cardiovascular diseases (Scalbert et al., 2005). The role of phenolics as antioxidants in the human body has prompted researchers to determine how their content and activity are affected by postharvest processing and storage conditions. Previous studies indicated an increase

Received for publication 12 Sept. 2007. Accepted for publication 4 Dec. 2007.

We thank Dr. Makoto Yoshimoto (Department of Upland Farming, Kyushu National Agricultural Experiment Station, Miyakonojo, Miyazaki, Japan) for providing standards for three isomers of isochlorogenic acid (4,5-dicaffeoylquinic acid, 3,5dicaffeoylquinic acid, and 3,4-dicaffeoylquinic acid).

${ }^{1}$ To whom reprint requests should be addressed; e-mailmpadda1@1su.edu in total phenolic content and antioxidant activity in fresh-cut carrots, potatoes, jicama roots, and lettuce (Aquino-Bolanos et al., 2000; Cantos et al., 2001, 2002; CisnerosZevallos, 2003). Sweetpotato roots are chilling-sensitive and controlled abiotic stress treatments such as wounding and storage of fresh-cut products at chilling injury (CI)inducing temperatures may enhance the nutraceutical value or health benefits through an increase in secondary metabolites such as phenolics (Dixon and Paiva, 1995). However, a recent study has indicated that the phenolic content and antioxidant capacity after wounding may decrease or increase depending on type of fruit and vegetable tissue and cultivar (Reyes et al., 2007).

Sweetpotato roots are a major staple food widely consumed in developing countries and rank as the third most important starchy food crop in the world (Food and Agriculture Organization of the United Nations, 2007). Like other vegetables, sweetpotato roots can also be consumed as a fresh-cut product and different style cuts have recently been marketed on a small scale. However, there is considerable potential for further market expansion of fresh-cut sweetpotato products. Minimally processed sweetpotato products such as shredded, sliced, or French-fry cuts may decrease preparation time for use in restaurants and other food service facilities. Sweetpotato roots have been reported to contain phenolic antioxidant compounds such as chlorogenic acid, caffeic acid, and dicaffeoylquinic acids with different antimutagenic effects (Walter et al., 1979; Yoshimoto et al., 2002). The increase in phenolic content and antioxidant activity was observed when whole sweetpotato roots were stored at CI-inducing temperatures (Padda and Picha, 2008a). Reyes et al. (2007) indicated the total phenolics and antioxidant capacity in shredded sweetpotatoes stored for $2 \mathrm{~d}$ at $15{ }^{\circ} \mathrm{C}$ increased by $17 \%$ and $12 \%$, respectively. However, information pertaining to the effect of temperature and storage on the total phenolics, individual phenolic acids, and antioxidant activity of different style fresh-cut sweetpotatoes was not presented. More detailed research on phenolic composition and antioxidant value of different style fresh-cut sweetpotatoes will be of increasing commercial importance as the demand for fresh-cut sweetpotato products increases. The purpose of this study was to quantify the changes in the phenolic composition and antioxidant activity in different style freshcut sweetpotatoes held at different temperatures and storage durations.

\section{Materials and Methods}

Chemicals and reagents. Chlorogenic and caffeic acid standards, Folin-Denis reagent, 1, 1-diphenyl-2-picrylhydazyl (DPPH) reagent, and Trolox (6-hydroxy-2, 5, 7, 8tetramethyl-chroman-2-carboxylic acid) antioxidant standard were purchased from SigmaAldrich (St. Louis). High-performance liquid chromatography-grade acetonitrile, 2-propanol, formic acid, and analytical grade methanol were procured from Fisher Chemicals (Fair Lawn, NJ).

Plant material and tissue preparation. Sweetpotato cv. Beauregard roots were grown at the Louisiana State University AgCenter Sweetpotato Research Station at Chase, LA, in the 2005 season. The roots were harvested during the first week of October and cured ( $30{ }^{\circ} \mathrm{C}, 90 \%$ relative humidity) for $7 \mathrm{~d}$ followed by storage at $15{ }^{\circ} \mathrm{C}, 90 \%$ relative humidity. Randomly selected roots were washed and dried at ambient temperature $\left(\approx 22{ }^{\circ} \mathrm{C}\right)$ before fresh-cut processing. Roots were then peeled with an abrasive peeler and processed into shreds $(\approx 2 \times 20 \mathrm{~mm})$, slices ( $\approx 5 \mathrm{~mm}$ thick), and French-fry cuts $(\approx 7 \times$ $10 \mathrm{~mm}$ ). A manual food processor was used for shredding, whereas the French-fry cut and slices were prepared using a Bron Coucke mandoline (Model no. 20638CHB; KitchenKapers, Cherry Hill, NJ). The fresh-cut material was sanitized by dipping in a $150 \mathrm{mg} \cdot \mathrm{L}^{-1}$ chlorine solution ( $\mathrm{pH} 6.5$ ) for $1 \mathrm{~min}$. The sanitized material was spin-dried using a salad spinner (Oxo International, New York, $\mathrm{NY}$ ) and a random sample of $100 \mathrm{~g}$ from each cut was heat-sealed in polyolefin bags (PD 941; Cryovac Sealed Air Corp., Duncan, SC) designed for high oxygen $\left(\mathrm{O}_{2}\right)$ transmission rate $\left(16.5 \mathrm{~m}^{3} \cdot \mathrm{atm}^{-1} \cdot \mathrm{m}^{-2} / 24 \mathrm{~h}\right)$ to allow aerobic respiration of fresh-cut produce. The bags of fresh-cut material were stored at two different temperatures, 0 and $5{ }^{\circ} \mathrm{C}$, and samples from each temperature were analyzed after 4 and $8 \mathrm{~d}$ of storage. Sweetpotatoes analyzed immediately after cutting ( $0 \mathrm{~d}$ of storage) served as the control. 
Headspace gas composition. The headspace gas composition inside the fresh-cut sweetpotatoes bags was monitored daily to observe the changes in $\mathrm{CO}_{2}$ and $\mathrm{O}_{2}$ during the storage period. The gas composition was determined using a Model $6600 \quad \mathrm{O}_{2} / \mathrm{CO}_{2}$ analyzer (Illinois Instruments, Ingleside, IL). An adhesive septum was affixed to the plastic bag to avoid any leakage after sampling. The bags were gently shaken before gas analysis to ensure the internal package gas atmosphere was homogenous.

Tissue extraction. After removal from storage, randomly selected tissue from each bag was lyophilized and powdered using a mortar and pestle. A sample weighing $0.5 \mathrm{~g}$ of powdered tissue was placed in a $15-\mathrm{mL}$ centrifuge tube (BD Biosciences, San Jose, CA) and $\approx 8 \mathrm{~mL}$ of $80 \%$ methanol in deionized water was added to the centrifuge tube. The tubes were capped and immersed in a water bath at $80{ }^{\circ} \mathrm{C}$ for $10 \mathrm{~min}$. After vigorously shaking the heated samples manually for $30 \mathrm{~s}$, the tubes were cooled and centrifuged at $4500 \mathrm{~g}_{\mathrm{n}}$ for $15 \mathrm{~min}$. The final volume of clear supernatant was made to 10 $\mathrm{mL}$ with $80 \%$ methanol and analyzed for total phenolic content, individual phenolic acids, and antioxidant activity. Extraction recoveries determined by spiking sweetpotato samples with known concentrations of each phenolic acid were $98 \%$ or greater.

Total phenolics. Total phenolic content was determined by a slight modification of the Folin-Denis method (Swain and Hillis, 1959). A sample volume of $0.5 \mathrm{~mL}$ was placed in a $25-\mathrm{mL}$ test tube followed by the addition of $8 \mathrm{~mL}$ of Megapure water (Barnstead MP-12A, Dubuque, IA) and $0.5 \mathrm{~mL}$ of Folin-Denis reagent, respectively. After $3 \mathrm{~min}, 1 \mathrm{~mL}$ of $1 \mathrm{~N} \mathrm{Na}_{2} \mathrm{CO}_{3}$ was added and the solution was allowed to stand for $2 \mathrm{~h}$ at ambient temperature $\left(\approx 22^{\circ} \mathrm{C}\right)$. Absorbance of the resulting blue complex was measured at $750 \mathrm{~nm}$ using an ultraviolet/visible (UV/Vis) spectrophotometer (Lambda 35; PerkinElmer Instruments, Norwalk, CT). A standard curve of chlorogenic acid was plotted with a concentration ranging from 50 to $300 \mu \mathrm{g} \cdot \mathrm{mL}^{-1}$. The total phenolic content was expressed as milligrams of chlorogenic acid equivalents per gram dry weight of sweetpotato tissue.

Individual phenolic acids. Isolation and quantification of individual phenolic acids was obtained using a reversed-phase highperformance liquid chromatography (Padda and Picha, 2007). An aliquot of the supernatant from the sweetpotato extract was filtered through a $0.45-\mu \mathrm{m}$ Nylaflo membrane filter (Pall Corp., East Hills, NY). A sample volume of $20 \mu \mathrm{L}$ was injected onto a Gemini C18, 5- $\mu \mathrm{m}, 4.6 \times 250$-mm column (Phenomenex, Torrance, CA) using a Waters 717 autosampler connected to a Waters $600 \mathrm{E}$ pump (Waters Corp., Milford, MA). Phenolic acids were eluted using a mobile phase consisting of $1 \%$ (by volume) formic acid in aqueous solution: acetonitrile: 2-propanol (70:22:8), $\mathrm{pH}$ 2.5. The column temperature was set to $30{ }^{\circ} \mathrm{C}$ and an isocratic elution with a flow rate of $0.75 \mathrm{~mL} \cdot \mathrm{min}^{-1}$ was performed. The peaks detected were identified and quantified by comparing the retention time and peak area with that of known standards. Quantification was based on absorbance at $320 \mathrm{~nm}$ using a Waters 2487 dual-wavelength ultraviolet absorbance detector.

Antioxidant activity. The antioxidant activity was measured using a method described by Brand-Williams et al. (1995) with little modifications (Padda and Picha, 2007). An aliquot $(300 \mu \mathrm{L})$ of sweetpotato extract was placed in a $1.5-\mathrm{mL}$ amber-colored centrifuge tube. Then $600 \mu \mathrm{L}$ of $0.1 \mathrm{M}$ 2-(N-morpholine) ethanesulfonic acid, $\mathrm{pH}$ 6.0 , and $300 \mu \mathrm{L}$ of $0.4 \mathrm{~mm}$ of DPPH solution were added to the centrifuge tube. The resultant mixture was shaken and held in the dark for $\approx 2 \mathrm{~min}$. The decrease in absorbance of DPPH free radicals at $520 \mathrm{~nm}$ was measured using a UV/Vis spectrophotometer. The sweetpotato extract replaced with $80 \%$ methanol was used as the control and a solution of $80 \%$ methanol without DPPH reagent was used as a blank. The antioxidant activity was calculated from a standard curve made with known concentrations of Trolox antioxidant and expressed as milligrams of Trolox equivalents per gram dry weight.

Statistical analysis. A completely randomized design with five replications per treatment was used. Each bag was considered as a replication and experiment was repeated. Data were analyzed by SAS procedure Mixed (SAS Institute, Cary, NC). Analysis of variance was performed and significance of differences among least square means was determined by Tukey's test $(P \leq 0.05)$.

\section{Results and Discussion}

Headspace gas composition. The changes in $\mathrm{CO}_{2}$ and $\mathrm{O}_{2}$ concentration in the headspace of fresh-cut sweetpotatoes stored in sealed PD941 bags are presented in Figures 1 and 2. In general, the headspace in bags stored at $5^{\circ} \mathrm{C}$ had higher levels of $\mathrm{CO}_{2}$ and lower levels of $\mathrm{O}_{2}$ than in the bags at $0{ }^{\circ} \mathrm{C}$, which was consistent with previous studies on fresh-cut sweetpotato slices (Erturk and Picha, 2007) and jicama roots (Aquino-Bolanos et al., 2000). Toward the end of the 8-d storage period at $5{ }^{\circ} \mathrm{C}$, the headspace of the shredded sweetpotatoes had higher levels of $\mathrm{CO}_{2}$ and lower levels of $\mathrm{O}_{2}$ than in the French-fry cut and sliced sweetpotatoes. In an earlier report, the higher respiration rate of shredded radishes compared with sliced and whole radishes indicated the respiratory response of tissue to mechanical wounding was directly related to the extent of tissue injury (Aguila et al., 2006). No significant differences in headspace gas composition were observed in the different style cut sweetpotatoes stored for $8 \mathrm{~d}$ at $0{ }^{\circ} \mathrm{C}$. After $4 \mathrm{~d}$ of storage, the $\mathrm{CO}_{2}$ and $\mathrm{O}_{2}$ content in bags containing shredded sweetpotato tissue showed a rapid increase and decrease, respectively. The $\mathrm{O}_{2}$ levels in all bags after $8 \mathrm{~d}$ of storage were sufficient to avoid anaerobic respiration and no visual decay, off-odors, or off-flavors developed.
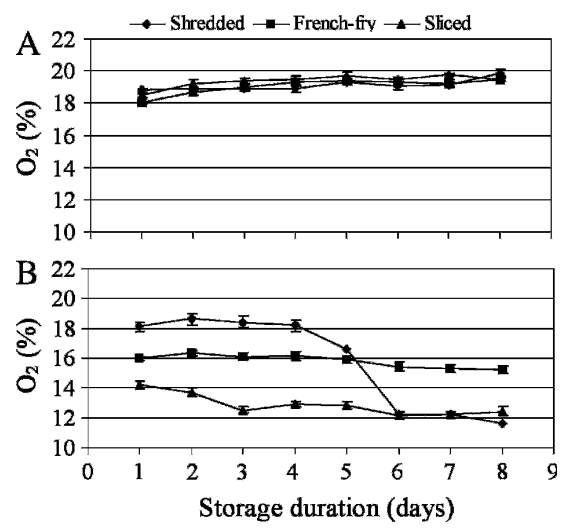

Fig. 1. Changes in headspace $\mathrm{O}_{2}$ (oxygen) levels in fresh-cut sweetpotatoes stored at $0{ }^{\circ} \mathrm{C}$ (A) and $5{ }^{\circ} \mathrm{C}(\mathbf{B})$. Vertical bars represent SE of the mean and, when absent, fall under the symbol.

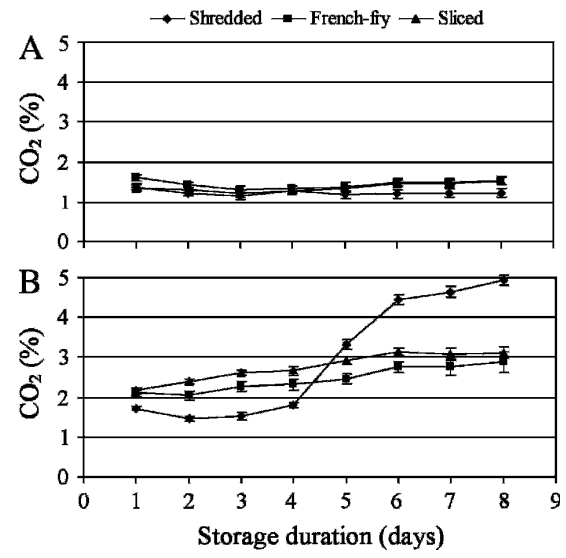

Fig. 2. Changes in headspace $\mathrm{CO}_{2}$ (carbon dioxide) levels in fresh-cut sweetpotatoes stored at $0{ }^{\circ} \mathrm{C}$ (A) and $5{ }^{\circ} \mathrm{C}($ B). Vertical bars represent SE of the mean and, when absent, fall under the symbol.

Previously, McConnell et al. (2005) mentioned that quality of shredded sweetpotatoes could be maintained for $7 \mathrm{~d}$ at $4{ }^{\circ} \mathrm{C}$. Additionally, this study indicated the respiration rate and quality of fresh-cut sweetpotatoes depends on the style of cut, storage temperature, and duration of storage.

Total phenolics. The total phenolic content in sweetpotato root tissue analyzed immediately after cutting (control) was 1.29 $\mathrm{mg} \cdot \mathrm{g}^{-1}$ dry weight and increased significantly after wounding depending on style of cut and storage temperature and duration. In general, total phenolic content in all types of fresh-cut sweetpotatoes stored at $5{ }^{\circ} \mathrm{C}$ increased with storage (Table 1). Irrespective of type of processing, the total phenolic content in fresh-cut sweetpotatoes stored at $5{ }^{\circ} \mathrm{C}$ for $8 \mathrm{~d}$ was significantly higher than after 4 $\mathrm{d}$ of storage. Although the respiration rate in shredded tissue stored at $5{ }^{\circ} \mathrm{C}$ for $8 \mathrm{~d}$ was higher than sliced and French-fry cut, the total phenolic content among the different style cuts of sweetpotatoes was not significantly different. The storage of fresh-cut sweetpotatoes at $0{ }^{\circ} \mathrm{C}$ resulted in a lower 
Table 1. Total phenolics and antioxidant activity during storage of fresh-cut sweetpotatoes.

\begin{tabular}{|c|c|c|c|c|}
\hline & \multicolumn{2}{|c|}{$\begin{array}{c}\text { Total } \\
\text { phenolics CAE } \\
\left(\mathrm{mg} \cdot \mathrm{g}^{-1} \text { dry wt) }\right.\end{array}$} & \multicolumn{2}{|c|}{$\begin{array}{c}\text { Antioxidant } \\
\text { activity TE } \\
\left(\mathrm{mg} \cdot \mathrm{g}^{-1} \text { dry wt) }\right.\end{array}$} \\
\hline & $0^{\circ} \mathrm{C}$ & $5^{\circ} \mathrm{C}$ & $0^{\circ} \mathrm{C}$ & $5^{\circ} \mathrm{C}$ \\
\hline \multicolumn{5}{|l|}{ Control } \\
\hline $0 \mathrm{~d}$ & $1.29 \mathrm{~d}^{\mathrm{z}}$ & $1.29 \mathrm{~d}$ & $0.78 \mathrm{~d}$ & $0.78 \mathrm{c}$ \\
\hline \multicolumn{5}{|c|}{ Shredded } \\
\hline $4 d$ & $1.30 \mathrm{~d}$ & $1.42 \mathrm{~cd}$ & $0.79 \mathrm{~d}$ & $1.06 \mathrm{c}$ \\
\hline $8 \mathrm{~d}$ & $1.33 \mathrm{~d}$ & $2.31 \mathrm{a}$ & $0.74 \mathrm{~d}$ & $1.77 \mathrm{~b}$ \\
\hline \multicolumn{5}{|c|}{ French-fry cut } \\
\hline $4 \mathrm{~d}$ & $1.44 \mathrm{~cd}$ & $1.65 \mathrm{bc}$ & $1.02 \mathrm{c}$ & $1.27 \mathrm{c}$ \\
\hline $8 \mathrm{~d}$ & $1.46 \mathrm{~cd}$ & $2.20 \mathrm{a}$ & $1.12 \mathrm{c}$ & $2.26 \mathrm{a}$ \\
\hline \multicolumn{5}{|l|}{ Sliced } \\
\hline $4 \mathrm{~d}$ & $1.50 \mathrm{bc}$ & $1.81 \mathrm{~b}$ & $1.15 \mathrm{c}$ & $1.57 \mathrm{~b}$ \\
\hline $8 \mathrm{~d}$ & $1.62 \mathrm{bc}$ & $2.44 \mathrm{a}$ & $1.14 \mathrm{c}$ & $2.37 \mathrm{a}$ \\
\hline
\end{tabular}

${ }^{2}$ Mean values $(\mathrm{n}=5)$ with the same letter within rows and columns are not significantly different at $P \leq 0.05$ (Tukey's test).

$\mathrm{CAE}=$ chlorogenic acid equivalents; $\mathrm{TE}=$ Trolox equivalents.

tissue respiration rate and only the sliced tissue had a significantly higher total phenolic content than the control. The total phenolic content in sliced tissue $\left(2.44 \mathrm{mg} \cdot \mathrm{g}^{-1}\right.$ dry weight) after $8 \mathrm{~d}$ of storage at $5{ }^{\circ} \mathrm{C}$ was $\approx 2$ fold higher than the total phenolic content immediately after cutting $\left(1.29 \mathrm{mg} \cdot \mathrm{g}^{-1}\right.$ dry weight). The results for total phenolic content in fresh-cut sweetpotatoes were consistent with a previous report, which found an increase in total phenolic content in freshcut Irish potatoes (Cisneros-Zevallos, 2003). The increase in total phenolic content in injured sweetpotato tissue at $10{ }^{\circ} \mathrm{C}$ was previously reported to be associated with increased phenylalanine ammonia-lyase and transcinnamic acid 4-hydroxylase activities (Reyes et al., 2007; Tanaka et al., 1974). However, our study provides information for the first time on changes in total phenolic content in different style fresh-cut sweetpotatoes stored at different temperatures and durations. Although phenolic compounds increased after $8 \mathrm{~d}$ of storage at $5{ }^{\circ} \mathrm{C}$, no visual tissue browning was observed. Consistent with our results, prior studies found no correlation between the degree of browning and accumulation of total phenolics in freshcut potatoes and lettuce (Cantos et al., 2001, 2002). Tissue injury resulting from peeling and cutting can facilitate microbial decay and increase the spoilage of fresh-cut produce. However, the increase in total phenolic content during storage of fresh-cut produce may contribute toward the tissue chemical defense mechanism against microbial decay (Chubey and Nylund, 1969). Dixon and Paiva (1995) reported that the induction of secondary metabolites after tissue injury is related to the wound healing process to fight pathogen attack. Also, dipping in chlorine solution after tissue preparation reduced the microbial load and maintained the marketable quality of the fresh-cut product after $8 \mathrm{~d}$ of storage (Erturk and Picha, 2006).

Individual phenolic acids. Consistent with a previous report, Table 2 indicates the most abundant phenolic acid in sweeetpotato roots was chlorogenic acid followed by 3,5-dicaffeoylquinic acid (Walter et al., 1979). In addition, this study indicated the content of five different phenolic acids in various types of fresh-cut sweetpotatoes generally increased many fold, reaching maximal levels on the eighth day of storage at $5{ }^{\circ} \mathrm{C}$. Storage temperature and style of cut significantly influenced the accumulation of phenolic acids. In general, the accumulation of phenolic acids at $5{ }^{\circ} \mathrm{C}$ was higher than at $0{ }^{\circ} \mathrm{C}$. In agreement with our results, the woundinduced synthesis of caffeic acid derivatives in lettuce was reported to be higher at $10{ }^{\circ} \mathrm{C}$ than at $5{ }^{\circ} \mathrm{C}$ and was attributed to a higher rate of metabolism at the higher temperature (Tomas-Barberan et al., 1997). The content of all phenolic acids, except 4,5-dicaffeoylquinic acid, in sweetpotato tissue was significantly higher after $8 \mathrm{~d}$ of storage at $5^{\circ} \mathrm{C}$ than immediately after cutting (control). Chlorogenic acid content $\left(539.9 \mu \mathrm{g} \cdot \mathrm{g}^{-1}\right.$ dry weight) in sliced cut sweetpotatoes stored at $5{ }^{\circ} \mathrm{C}$ for $8 \mathrm{~d}$ was 6 -fold higher than the initial content $\left(88.3 \mu \mathrm{g} \cdot \mathrm{g}^{-1} \mathrm{dry}\right.$ weight). At the end of $8 \mathrm{~d}$ of storage, sliced sweetpotato tissue had a significantly higher amount of chlorogenic acid than the other style cuts. However, the content of 3,4-dicaffeoylquinic acid was significantly higher in the shredded cut compared with the other style cuts. A dramatic increase in the content of chlorogenic acid and its derivatives has been previously described in fresh-cut potato strips and shredded carrots stored at $4{ }^{\circ} \mathrm{C}$ (Babic et al., 1993; Tudela et al., 2002). This study indicated the style of cut or degree of tissue injury may induce the production of specific types of phenolic acids. Utilization of different kinds of stresses to increase production of specific phenolic acids with precise health benefits may be helpful in promoting fresh-cut sweetpotatoes as a functional food.

Antioxidant activity. In general, the trend of change in antioxidant activity with time and temperature paralleled that of total phenolic content (Table 1). The initial antioxidant activity of sweetpotato roots analyzed immediately after cutting (control) was 0.78 $\mathrm{mg} \cdot \mathrm{g}^{-1}$ dry weight. All treatments, except shredded sweetpotatoes stored at $0{ }^{\circ} \mathrm{C}$, resulted in a significant increase in antioxidant activity compared with the control. Also, the fresh-cut sweetpotatoes stored at $5{ }^{\circ} \mathrm{C}$ for $8 \mathrm{~d}$ had a significantly higher antioxidant activity than after $4 \mathrm{~d}$ of storage. At $0{ }^{\circ} \mathrm{C}$, duration of storage interval within the same style cut had no significant effect on antioxidant activity. Comparison of different style cuts revealed that sliced and Frenchfry cut sweetpotatoes stored at $5{ }^{\circ} \mathrm{C}$ for $8 \mathrm{~d}$ accumulated higher antioxidant activity than shredded sweetpotatoes. However, antioxidant activity in shredded sweetpotatoes stored at $5{ }^{\circ} \mathrm{C}$ for $4 \mathrm{~d}$ was not significantly different from French-fry cut sweetpotatoes. The highest antioxidant activity $\left(2.37 \mathrm{mg} \cdot \mathrm{g}^{-1}\right.$ dry weight) in sliced tissue stored for $8 \mathrm{~d}$ at $5{ }^{\circ} \mathrm{C}$ was $\approx 3$-fold higher than the initial antioxidant activity $\left(0.78 \mathrm{mg} \cdot \mathrm{g}^{-1}\right.$ dry weight $)$ of sweetpotatoes. An increase in antioxidant

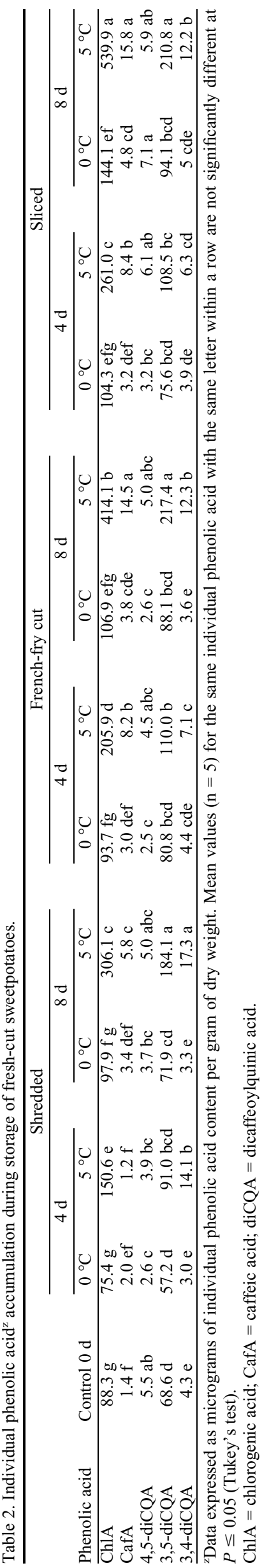


capacity in shredded sweetpotato tissue stored for $2 \mathrm{~d}$ at $15{ }^{\circ} \mathrm{C}$ was recently reported (Reyes et al., 2007). However, to the best of our knowledge, the effect of wounding intensity and storage temperature and duration on antioxidant activity in sweetpotatoes has not been described before this report. The accumulation of phenolic compounds may be a key factor responsible for increased antioxidant activity of fresh-cut sweetpotatoes. Our previous study has illustrated a strong correlation $(\mathrm{r}=0.98)$ between phenolic compounds and antioxidant activity (Padda and Picha, 2008c). A comparison of different vegetables consumed in the United States indicated that sweetpotatoes contain higher total phenolics and antioxidant activity than carrots and Irish potatoes (Vinson et al., 1998). However, as a result of lower percapita consumption, daily intake of phenol compounds from sweetpotatoes was $5 \mathrm{mg}$ compared with 7 and $20 \mathrm{mg}$ from carrots and Irish potatoes, respectively.

\section{Conclusions}

Abiotic stresses such as mechanical wounding during tissue preparation and subsequent low-temperature storage of fresh-cut sweetpotatoes can induce the accumulation of phenolic compounds. The increased antioxidant activity from a higher content of phenolic compounds may enhance the nutraceutical value and health beneficial properties of freshcut sweetpotatoes. Despite increased phenolic content and antioxidant activity after $8 \mathrm{~d}$ of storage, no tissue browning, off-flavors, and off-odors were observed and the products were considered marketable. This information may be useful to the food industry in targeting fresh-cut sweetpotato as a convenience food with increased health benefits.

\section{Literature Cited}

Aguila, J.S., F.F. Sasaki, L.S. Heiffiga, E.M.M. Ortega, A.P. Jacomino, and R.A. Kluge. 2006. Fresh-cut radish using different cut types and storage temperatures. Postharvest Biol. Technol. 40:149-154.

Aquino-Bolanos, E.N., M.I. Cantwell, G. Peiser, and E. Mercado-Silva. 2000. Changes in the quality of fresh-cut jicama in relation to storage temperatures and controlled atmospheres. J. Food Sci. 65:1238-1243.

Babic, I., M.J. Amiot, C. Nguyen, and S. Aubert. 1993. Changes in phenolic content in fresh ready-to-use shredded carrots during storage. J. Food Sci. 58:351-355.

Brand-Williams, W., M.E. Cuvelier, and C. Berset. 1995. Use of a free-radical method to evaluate antioxidant activity. Lebensmittel-Wissenschaft Technologie 28:25-30.

Cantos, E., J.C. Espin, and F.A. Tomas-Barberan. 2001. Effect of wounding on phenolic enzymes in six minimally processed lettuce cultivars upon storage. J. Agr. Food Chem. 49:322-330.

Cantos, E., J.A. Tudela, M.I. Gill, and J.C. Espin. 2002. Phenolic compounds and related enzymes are not rate-limiting in browning development of fresh-cut potatoes. J. Agr. Food Chem. 50: 3015-3023.

Chubey, B.B. and R.E. Nylund. 1969. Surface browning in carrots. Can. J. Plant Sci. 49: 421-426.

Cisneros-Zevallos, L. 2003. The use of controlled postharvest abiotic stresses as a tool for enhancing the nutraceutical content and adding-value of fresh fruits and vegetables. J. Food Sci. 68: 1560-1565.

Dixon, R.A. and N.L. Paiva. 1995. Stress-induced phenylpropanoid metabolism. Plant Cell 7: 1085-1097.

Erturk, E. and D.H. Picha. 2006. Microbiological quality of fresh-cut sweet potatoes. Intl. J. Food Sci. Tech. 41:366-374.

Erturk, E. and D.H. Picha. 2007. The effects of packaging film and storage temperature on internal package atmosphere and fermentation enzyme activity of sweetpotato slices. J. Food Proc. Preserv. (in press).

Food and Agriculture Organization of the United Nations. 2007. Statistical database, 15 Aug. 2007. <http://faostat.fao.org/site/370/default. aspx.>.

McConnell, R.Y., V.-D. Troung, W.M. Walter, Jr., and R.F. McFeeters. 2005. Physical, chemical, and microbial changes in shredded sweetpotatoes. J Food Proc. Preserv. 29:246-267.

Padda, M.S. and D.H. Picha. 2007. Methodology optimization for quantification of total phe- nolics and individual phenolic acids in sweetpotato (Ipomoea batatas L.) roots. J. Food Sci. 72:C412-C416.

Padda, M.S. and D.H. Picha. 2008a. Effect of low temperature storage on phenolic composition and antioxidant activity of sweetpotatoes. Postharvest Biol. Technol. 47:176-180.

Padda, M.S. and D.H. Picha. 2008b. Phenolic composition and antioxidant capacity of different heat-processed forms of sweetpotato cv. 'Beauregard'. Int. J. Food Sci. Tech. (in press).

Reyes, L.F., J.E. Villarreal, and L. CisnerosZevallos. 2007. The increase in antioxidant capacity after wounding depends on the type of fruit or vegetable tissue. Food Chem. 101: 1254-1262.

Scalbert, A., C. Manach, C. Morand, C. Remesy, and L. Jimenez. 2005. Dietary polyphenols and the prevention of diseases. Crit. Rev. Food Sci. Nutr. 45:287-306.

Swain, T. and W.E. Hillis. 1959. The phenolic constituents of Prunus domestica I. The quantitative analysis of phenolic constituents. J. Sci. Food Agr. 10:63-68.

Tanaka, Y., M. Kojima, and I. Uritani. 1974. Properties, development and cellular- localization of cinnamic acid 4-hydroxylase in cutinjured sweet potato. Plant Cell Physiol. 15:843-854.

Tomas-Barberan, F.A., J. Loaize-Velarde, A. Bonfanti, and M.E. Saltveit. 1997. Early woundand ethylene-induced changes in phenylpropanoid metabolism in harvested lettuce. J. Amer. Soc. Hort. Sci. 122:399-404.

Tudela, J.A., E. Cantos, J.C. Espin, F.A. TomasBarberan, and M.I. Gil. 2002. Induction of antioxidant flavonol biosynthesis in fresh-cut potatoes. Effect of domestic cooking. J. Agr. Food Chem. 50:5925-5931.

Vinson, J.A., Y. Hao, X. Su, and L. Zubik. 1998. Phenol antioxidant quantity and quality in foods: Vegetables. J. Agr. Food Chem. 46:3630 3634.

Walter, W.M., A.E. Purcell, and G.K. McCollum. 1979. Use of high-pressure liquid-chromatography for analysis of sweet-potato phenolics. J. Agr. Food Chem. 27:938-941.

Yoshimoto, M., S. Yahara, S. Okuno, M.S. Islam, K. Ishiguro, and O. Yamakawa. 2002. Antimutagenicity of mono-, di-, and tricaffeoylquinic acid derivatives isolated from sweetpotato (Ipomoea batatas L.) leaf. Biosci. Biotechnol. Biochem. 66:2336-2341. 